\title{
The Politics of Public History Education
}

\section{Commentary}

Any consideration of the future of public history in K-12 education must begin the fundamental question of why we teach history in the schools at all? A survey of educators, politicians, parents, and random citizens of any state would likely turn up answers such as: "To help children become better citizens," or, “To help children understand what it means to be German, Russian, Chinese, or whoever 'we' are," or, “To help children become more critical consumers of information about the world they live in." The notion that we must teach our children about the past is so ingrained in educational theory that to even consider dropping history from the curricula seems absurd.

But what history? Whose history? Which version of the past will help them become the kind of citizens 'we' want, or to understand the essential characteristics of our nation or culture, or to turn into the critical consumers of information we hope they'll become? These are the questions that bedevil educators, that often lead to intense and rancorous debates in legislative chambers, and that inspire journalists and social commentators to new heights of national rhetoric. How could it be that great leader X isn't highlighted in the curriculum? How could it be that the new curriculum fails to glorify the greatness of our nation? How could it be that our children are being taught a version of the past at odds with the values my generation holds dear?

Choose almost any national education system in the post-World War II era and you can find one or more examples of intense debates about what should and should not be taught to our children about the past - debates that almost never happen in any other discipline. Mathematics educators argue endlessly about the best methods for teaching children, but not about the content. Math students first learn numeracy, then calculations, then more abstract mathematics such as algebra, geometry, and trigonometry, before proceeding on to calculus. Teachers of language similarly argue over the best methods for promoting language acquisition, but none (or almost none) argues about the importance of vocabulary, grammar, syntax, and the ability to read, write, and speak a language. But the choices of content made by mathematics and 
language teachers never (or almost never) become the subject of parliamentary debates. Only history comes in for such scrutiny. ${ }^{1}$

Because so many school-aged children encounter the past through public history - at museums, historic sites, and increasingly through digital public history websites - teaching our children how to "read" public history, just as we teach them to read primary and secondary sources, is essential to their maturation as consumers of the past. But as both Professor Alexander Khodnev and Professor Charlotte Bühl-Gramer point out, there is a broad disconnect between the need to teach young people public history skills and the reality of their curricula. Khodnev and Bühl-Gramer are writing about Russia and Germany, but one could say much the same about the United States, where public history skills are almost entirely absent from K-12 history curricula.

As both authors describe in their essays on Public History in their respective national contexts, politics lie at the heart of the problem. Khodnev points out that in post-Soviet Russia, history museums are "designed to enshrine a particular version of history," which means that the space within which a more critically conceived public history might exist is filled instead with "the politics of history." Similarly, in Germany, the existence of "ideologically driven and abusive efforts at remaking the past" by those outside the educational complex means that German students who visit public history sites, whether in person or online, confront the intersection of political and educational imperatives but are generally not taught to discern where public history ends and politics begins. Given this reality in both Germany and Russia, Khodnev and Bühl-Gramer rightfully call our attention to the unsystematic adoption of public history in their respective school curricula, a lacuna that makes it all the more difficult for students to learn how to critically assess the content of the narratives presented in such sites.

Of course, this is not simply a Russian or a German problem. The American educational system has a long history of ignoring public history skills in its curricula. The problem is, in some ways, more acute in the United States because we have, in effect, fifty-two different history curricula (one for each state, plus Puerto Rico and the District of Columbia), and an umbrella set of nominal national standards called the Common Core that states are increasingly being forced to adopt or at least adapt to. ${ }^{2}$ Neither the Common Core standards, nor a random sample of ten state history curricula examined for this essay make any mention of what might be called a "public history" skill or competency. At the level of

1 For a recent example from the American context, see Keith Erekson, ed., Politics and the History Curriculum: The Struggle over Standards in Texas and the Nation, (London: Palgrave MacMillan, 2012). 2 Common Core State Standards Initiative, accessed September 16, 2016, www.corestandards.org. 
American higher education, the "History Discipline Core," recently adopted by the American Historical Association also makes no specific mention of anything that might be called a public history skill or competency, focusing instead of critical reading of primary sources, writing, and classroom presentation skills. ${ }^{3}$ Recent debates in Québec, Canada on the importance of narrative or competency in school history reflect a similar dynamic. ${ }^{4}$

Bühl-Gramer is correct to argue that schools can evolve into powerful public history agents, identifying partnerships between schools and nearby museums, archives, historic sites, and political authorities to both create a growing market for public history and to help teach students the public history skills they need to function as critical consumers of historical content. It is certainly the case that in all three countries under consideration here - Russia, Germany, and the United States - K-12 history educators take advantage of the opportunities afforded by public history sites to help create emotional, visual, or tactile connections between their students and the past. ${ }^{5}$ But as both Bühl-Gramer and Khodnev argue, if these young people are not taught in a systematic and consistent way the skills for analyzing what they find at these sites, then they are very susceptible to the underlying politicization of the exhibit.

A well-known case of this exact problem happened in the United States in 1994. The Smithsonian Institution's Air and Space Museum, arguably the most visited history museum in the world at that time with more than eight million annual visitors, staged an exhibit about the dropping of the atomic bombs on Japan in 1945. As the opening of the exhibition drew near, a very public and highly politicized debate raged over the content of that exhibition - known afterwards as the Enola Gay exhibit. To some, especially veterans groups and some members of Congress, the original plan for the exhibition paid too much attention to the dropping of the atomic bombs as the beginning of the nuclear era in world affairs. Instead, these critics argued, the exhibition should have focused on the fact that by dropping these bombs on Hiroshima and Nagasaki, the United States brought the Second World War to a close and minimized American casualties in the process.

3 The History Discipline Core, American Historical Association Tuning Project, accessed September 18, 2016, www.historians.org/teaching-and-learning/tuning/history-discipline-core. 4 Stéphane Lévesque, "Going beyond "Narratives" vs. "Competencies": A model of history education,” Public History Weekly, 4 (2016) 12, accessed September 8, 2016. DOI: dx.doi.org/10.1515/ phw-2016-5918

5 "Evoking the Past", accessed September 18, 2016, teachinghistory.org/best-practices/usingprimary-sources/24135 
Historians weighed in on both sides of the controversy, as did journalists, politicians, and members of the general public. As Khodnev points out in his essay on the politicization of Russian history museums, what was at issue in the Enola Gay controversy was not simply what the content of the exhibition should or should not be, but also who should decide what that content should or should not be. ${ }^{6}$ In the end, the final version of the exhibition, which I toured with my own students, made little mention of the dawn of the nuclear era in international relations. Curators did manage to keep a significant portion of the original content on the aftermath of the bombings for the residents of Hiroshima and Nagasaki, but the overriding theme of the exhibit was that the bombings won the war.

Bühl-Gramer and Khodnev argue that we must include public history as one of the core historical competencies we teach to our students. How else can they assess critically narratives like the one presented in the Enola Gay exhibit? How else can they understand the "politics of history"? How else can they understand the intersection of politics and the public history content they are interacting with? In none of the three national contexts referenced here is it easy to imagine a path forward for increasing the engagement of school history curricula with a critical examination of public history competencies and concepts. Bühl-Gramer's previously mentioned call for partnerships between the schools and local public history sites can have a beneficial effect for both partners - increased visitor traffic and engagement for the sites and new and critically engaged learning opportunities for the students and thus offers one possible avenue for change. Such partnerships would, as Bühl-Gramer argues, require a much more systematic approach to teaching K-12 teachers about public history, its methods, and its history. Am I optimistic that such partnerships will result in substantive curricular change? Not in the immediate term. But we have to start somewhere and partnerships between public history sites and their local schools seem, for now, to be the only fruitful avenue for initiating change from below.

\section{Literature cited}

AHA History Tuning Project: 2016 History Discipline Core. Accessed September 18, 2016. www. historians.org/teaching-and-learning/tuning/history-discipline-core.

Chhaya, Priya, Jin Prugsawan. "Evoking the Past " (video). National History Education Clearing House Accessed September 18, 2016. teachinghistory.org/best-practices/using-primary-sources/24135.

6 Neil A. Lewis, "Smithsonian Substantially Alters Enola Gay Exhibit After Criticism," New York Times, October 1, 1994. 
Common Core State Standards Initiative. Accessed September 16, 2016. www.corestandards. org.

Erekson, Keith ed. Politics and the History Curriculum: The Struggle over Standards in Texas and the Nation. London: Palgrave MacMillan, 2012.

Lévesque, Stéphane. Going beyond “Narratives” vs. "Competencies”: A model of history education. Public History Weekly, 4 (2016) 12. Accessed September 8, 2016. DOI: dx.doi. org/10.1515/phw-2016-5918

Lewis, Neil A. "Smithsonian Substantially Alters Enola Gay Exhibit After Criticism," New York Times, October 1, 1994. 
